\title{
Sprawozdanie z prac w Papieskim Instytucie Studiów Kościelnych w 2017 r.
}

W ramach pomocy instytucjom polonijnym z ramienia Naczelnej Dyrekcji Archiwów Państwowych w Warszawie przebywałam dwukrotnie we wrześniu i październiku 2017 r. w Papieskim Instytucie Studiów Kościelnych w Rzymie.

Celem wyjazdów było kontynuowanie prac nad sporządzaniem ewidencji zasobu Instytutu.

W trakcie pobytu (wspólnie z dr Lidią Potykanowicz-Sudą z Archiwum Państwowego w Gdańsku) przejrzano 12,72 mb archiwaliów. Spośród nich rozpoznano i wyodrębniono 12 zespołów archiwalnych, którym nadano kolejne numery, nazwy, określono daty skrajne i wpisano do bazy SEZAM. Dodatkowo uzupełniono o informacje odnoszące się do aktotwórcy i niemal we wszystkich zespołach o informacje dotyczące ich zawartości Są to następujące zespoły:

Nr 10 - Zbiór materiałów archiwalnych dotyczących Polskich Sił Zbrojnych na Zachodzie 1939-2016;

$\mathrm{Nr} 11$ - Zbiór materiałów archiwalnych dotyczących arcybiskupa Józefa Gawliny 1942-2006;

Nr 12 - Spuścizna literacka Wojciecha Bąka (1907-1961; pisarz, prozaik, poeta) 1936-1979;

Nr 13 - Spuścizna Stefanii Okuniewskiej (1885-1974) 1851-1973;

Nr 14 - Spuścizna rodziny Szenwiców 1913-1978;

Nr 15 - Ambasada RP w Rzymie - szczątek zespołu 1926-1930;

Nr 16 - Radca handlowy przy Ambasadzie RP w Rzymie 1934-1939;

Nr 17 - Poselstwo RP w Pradze - szczątek zespołu 1938-1939;

Nr 18 - Katolicka Służba Pomocy w Bejrucie 1949-1959;

Nr 19 - Polskie Liceum i Gimnazjum Ogólnokształcące w Rzymie 1939-1948;

Nr 20 - Instytut im. Mikołaja Kopernika w Rzymie 1946-1948;

Nr 21 - Spuścizna Jerzego Langmana (1903-1982; ksiądz, profesor, historyk sztuki) 1940-1982;

Nr 22 - Spuścizna rodziny Siemiradzkich 1852-1973;

Nr 23 - Spuścizna Karola Badury (1907-1983; malarz, akwarelista) 1945-1987;

$\mathrm{Nr} 24$ - Hospicjum Polskiego Związku Kawalerów Maltańskich w Rzymie 1960-2004;

Nr 25 - Spuścizna Witolda Wehra (1901-1980; historyk sztuki, doktor praw) 1948-1967.

W związku z dużym nakładem pracy przy ustalaniu zawartości poszczególnych zespołów zdecydowano się dodatkowo sporządzić ewidencję w bazie IZA (inwentarz, spis roboczy) dla zespołów nr 12-20, 22, 24-25. Łącznie wpisano 238 rekordów. Ponadto ufor- 
mowano jednostki archiwalne, opisano i osygnowano, a następnie zapakowano do pudeł z tektury bezkwasowej.

Prawie wszystkie zespoły wpisane do bazy SEZAM posiadają ewidencję (IZA, MS Word), poza zespołem nr 21 i 23. W celu właściwego ich udostępniania postanowiono opracować dla Instytutu zasady korzystania z archiwaliów (regulamin pracowni, rewers, ankieta). Powyższe informacje zostały umieszczone także na stronie internetowej Papieskiego Instytutu Studiów Kościelnych (http://pisk.jezuici.pl/). Ponadto zamieszczono na stronie Instytutu dostosowane (PDF) wydruki inwentarzy z bazy IZA i MS Word.

Mariola Szaleniec

Archiwum Narodowe w Krakowie 